\title{
DEPRESSION AND ASSOCIATED FACTORS AMONG STUDENTS STUDYING IN HIGHER SECONDARY SCHOOLS IN NORTH KERALA
}

\author{
Liby Mary Victor ${ }^{1}$, Usha Karunakaran ${ }^{2}$
}

1 Junior Resident, Department of Community Medicine, Academy of Medical Sciences, Pariyaram, Kannur, Kerala, India.

${ }^{2}$ Professor, Department of Community Medicine, Academy of Medical Sciences, Pariyaram, Kannur, Kerala, India.

\begin{abstract}
BACKGROUND
ABSTRACT

The academic performance of higher secondary school students plays a crucial role in deciding about next stage of education and career. They belong to middle and late adolescence. Depression is the number one cause of illness and disability in this age group. The adolescents those who are affected with depression early in life often suffer from depression throughout their lives. Adolescents who are depressed have an increase in suicidal tendency and are at higher risk of anxiety, conduct disorders, substance abuse and poor academic achievement. The study intends to identify the prevalence of depression and associated factors.

The aim of this study is to estimate the prevalence of depression among higher secondary school students and to identify the factors associated with depression.
\end{abstract}

\section{MATERIALS AND METHODS}

A cross-sectional study was conducted among 640 adolescents studying in classes XI and XII in higher secondary schools in Taliparamba Taluk, Kannur District, Kerala. In the first stage, students were administered a pretested semi-structured questionnaire (for associated factors) and Patient Health Questionnaire PHQ-9 (for screening). Those students who were found positive were interviewed using the Hamilton's Rating Scale for Depression (HAM-D). Statistical measures like Chi-square test and Fisher's exact test were analysed using SPSS version 16.

\section{RESULTS}

The prevalence of depression was found to be $20.6 \%$. Majority of the students had mild depression (12.8\%). Depression was found to be more among males (21.5\%) compared to females (19.4\%). Factors like age, class of study, father's educational status, neglect, physical abuse, failure in exams, death of parents/ relatives, conflict in the family, poor communication, parental rejection, peer rejection, family history of depression, having someone to discuss worries with, career and university disagreement between the student and the parent were significantly associated with depression.

\section{CONCLUSION}

This study highlights the common but ignored problem of depression in adolescence. Early screening should be instituted in schools by adequately trained counsellors. Teachers, parents, healthcare workers and primary care providers should be trained to identify depression at early stage.

\section{KEY WORDS}

Prevalence; Adolescent; Depression; Higher Secondary School Students.

HOW TO CITE THIS ARTICLE: Victor LM, Karunakaran U. Depression and associated factors among students studying in higher secondary schools in North Kerala. J. Evolution Med. Dent. Sci. 2018;7(35):3894-3899, DOI: 10.14260/jemds/2018/871

\section{BACKGROUND}

WHO defines 'Adolescents' as individuals in the age group of 10 - 19 years that occurs after childhood and before adulthood. ${ }^{1}$ Adolescents are classified into early adolescents (10 - 14 years), middle adolescents (15 - 17 years) and late adolescents $(18-19$ years $) .^{2}$ There are a spectrum of health issues affecting adolescents which include nutrition, injuries, mental health, tobacco, alcohol and drug use, sexual and reproductive health and violence. The transition period from childhood to adulthood is a stage marked by emotional instability that makes adolescents vulnerable to depression. ${ }^{3}$

'Financial or Other Competing Interest': None.

Submission 11-07-2018, Peer Review 11-08-2018,

Acceptance 18-08-2018, Published 27-08-2018.

Corresponding Author:

Dr. Liby Mary Victor,

Junior Resident, Department of Community Medicine,

Academy of Medical Sciences, Pariyaram,

Kannur-670503, Kerala, India.

E-mail: libymv@gmail.com

DOI: $10.14260 /$ jemds $/ 2018 / 871$

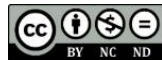

WHO's "Health for the world's adolescents" report reveals that depression is the predominant cause of illness and disability for both boys and girls aged 10 to 19 years. Globally, depression is the number one cause of illness and disability in this age group, and suicide ranks number 3 among causes of death. ${ }^{3}$ Depressive disorders are identified by WHO as priority mental health disorder of adolescence because of its high prevalence, recurrence, ability to cause significant complications and impairment. ${ }^{4}$ The lifetime prevalence for major depression in adolescence is $15 \%$ to $20 \%$ globally. ${ }^{5}$ In India out of 1.25 billion people, the estimated number of adolescents is 243 million. About $20 \%$ adolescents need mental health services. $20 \%$ of adolescents experience depression, mood disturbances, substance abuse, suicidal behaviours and eating disorders. ${ }^{6}$ A study conducted by Russell $\mathrm{P}$ et al found the prevalence of adolescent depression to be $13.9 \% .^{7}$ The National Mental Health Survey (NMHS) 2015 - 16 reported a prevalence rate of $0.8 \%$ for depression among 13 to 17 -year-old children. ${ }^{8}$

Higher secondary school students refer to students studying in classes XI and XII. ${ }^{9}$ They belong to middle and late 
adolescence. ${ }^{2}$ Higher secondary school education is a very important turning point in the academic life of the individual. The academic performance of the adolescents plays a crucial role in deciding about next higher stage of education and career. Students have to face many academic burdens, competition with other classmates and need to fulfil teacher's and parents' academic expectations. The threat of unemployment and absence of adequate opportunities dishearten the students. ${ }^{10}$

Depressed disorders are characterised by the presence of depressed moods along with a set of additional symptoms persisting over time, causing disruption and impairment of function. The individual suffers from depressed mood, loss of interest and enjoyment and reduced energy leading to increased fatigability and diminished activity. Marked tiredness after only slight effort is common. Other common symptoms are reduced concentration and attention, reduced self-esteem and self-confidence, ideas of guilt and unworthiness, bleak and pessimistic views of the future, ideas or acts of self-harm or suicide, disturbed sleep and diminished appetite. ${ }^{11}$

Depression in adolescents has received little research intention. There is a notion that adolescents are cognitively immature to be depressed and the concept that psychopathological manifestations represent normal development process of adolescence. 12 The adolescents those who are affected with depression early in life often suffer from depression throughout their lives. ${ }^{13}$ Adolescents who are depressed have an increase in suicidal tendency. They are at a higher risk of disorders such as anxiety, conduct disorders and substance abuse and poor academic achievement. ${ }^{14}$ Therefore, early screening to identify and treat depression is needed to prevent the development of adulthood depression and other mental disorders. Only few studies have been conducted on depression in Kerala. The study intends to identify the prevalence of depression and associated factors of depression.

\section{Objectives}

1. To estimate the prevalence of depression among students attending higher secondary schools in Taliparamba Taluk, Kannur, Kerala.

2. To identify the factors associated with depression among the study population.

\section{MATERIALS AND METHODS}

Study Design- A population based cross-sectional study was conducted from August 2016 to August 2017.

\section{Study Setting}

Government and private higher secondary schools in Taliparamba Taluk, Kannur district, Kerala. The study was conducted in Taliparamba Taluk. There were 30 government schools and 19 private schools in this Taluk. Out of this, 10 schools were in urban area and 39 schools were in rural area.

\section{Study Population}

Students studying in classes XI and XII in government and private higher secondary schools in Taliparamba Taluk, Kannur.

\section{Inclusion Criteria}

1. Students studying in classes XI and XII (Higher secondary schools) from selected sections.

2. Providing written informed consent.

\section{Exclusion Criteria}

1. Students who were not willing to participate in the study.

2. Prolonged absentees.

\section{Sampling}

Stratified random sampling was used. Schools in Taliparamba Taluk was divided into urban and rural schools. Within each strata, one government school and one private school was selected randomly. Thus, four schools were selected. Within each school, two sections were selected randomly from each of the classes XI and XII.

\section{Sample Size}

After applying inclusion and exclusion criteria, a total of 640 students were enrolled in the study.

\section{Study Tools}

1. A pre-tested semi-structured questionnaire.

2. The Patient Health Questionnaire (PHQ-9) was used as a screening test to identify students with depression. It is a validated test. (79) PHQ-9 consists of 9 items. Next to each item, there is a grading to assess how often these problems affected the students. Based on the response, the score is 0 for 'not at all,' 1 for 'several days,' 2 for 'more than half the days' and 3 for 'nearly every day.' These scores are added to get a total score. Those students with a score of 5 or more were identified as having depression. In addition, those students who scored $\geq 1$ for any ' 2 ' of the three items "Little interest or pleasure in doing things," "Feeling down, depressed or hopeless" and "Feeling tired or having little energy" will be considered as having depression. This scoring method was adopted based on the fact that these items have been cited as cardinal features of depression in ICD-10 classification.

3. The Hamilton's depression rating scale (HAM-D) consisted of 17 items. It is a validated test to rate the severity of depression. (80) The scores for each item were added to get a total score. This was used to rate the severity of depression.

\section{Data Collection Method}

The study was conducted in Taliparamba Taluk of Kannur district, Kerala. Approval for the study was obtained from the Institutional Ethical Committee. Consent was obtained from the Regional Deputy Director of Higher Secondary Education. The list of schools under Taliparamba Taluk was obtained. Schools were divided into urban and rural. From each of these, one government and private school were selected randomly. Consent was obtained from the Principal for each school. Consent forms were given to the students. Those who were willing to participate, the students brought their forms signed by the parents. The study was conducted in two stages: In the first stage, the students were administered the semi-structured questionnaire and PHQ-9. This was selfadministered. Information was collected on socio- 
demographic characteristics and associated factors using a semi-structured questionnaire. Those students who scored above the cut-off were taken up for the second stage using HAM-D to assess the severity of depression. This scale was investigator administered. Socioeconomic status (SES) was assessed using Revised Modified Kuppuswamy's socioeconomic status scale 2016.

\section{Statistical Analysis}

The data was entered in Microsoft Excel 2007 and analysed using SPSS version 16.0 software. The descriptive statistical methods like mean, standard deviation, frequencies and proportion were used. Mean inferential statistics like Chisquare test and Fisher's exact test were used to test the significance between associated factors and adolescent depression. A ' $p$ ' value of less than 0.05 was taken as significant.

\section{Ethical Considerations}

The study was conducted in Taliparamba Taluk of Kannur district, Kerala. Approval for the study was obtained from the Institutional Ethical Committee. Consent was obtained from the Regional Deputy Director of Higher Secondary Education.

\section{RESULTS}

\begin{tabular}{|c|c|c|}
\hline Characteristics & Number (n) & Percentage (\%) \\
\hline \multicolumn{3}{|c|}{ Age (In Years) } \\
\hline 15 & 54 & 8.5 \\
\hline 16 & 300 & 46.9 \\
\hline 17 & 262 & 40.9 \\
\hline 18 & 22 & 3.4 \\
\hline 19 & 2 & 0.3 \\
\hline Male & 367 & 57.3 \\
\hline Female & 273 & 42.7 \\
\hline \multicolumn{3}{|c|}{ Class of Study } \\
\hline X1 & 326 & 50.9 \\
\hline XII & 314 \\
\hline Religion \\
\hline Hindu & 366 & 59.1 \\
\hline Muslim & 259 \\
\hline Christian & 15 & 40.5 \\
\hline \multicolumn{3}{|c|}{ Type of Family } \\
\hline Nuclear & 372 \\
\hline Joint & 268 \\
\hline Table 1. Socio-Demographic Characteristics of Study \\
\hline \multicolumn{2}{|c|}{ Population } \\
\hline
\end{tabular}

In the present study, $50 \%$ of the students were from urban area and $50 \%$ were from rural area. $50 \%$ of the students were from government school and $50 \%$ were from private school.

\begin{tabular}{|c|c|c|}
\hline Characteristics & Number (n) & Percentage (\%) \\
\hline \multicolumn{2}{|c|}{ No. of Family Members } \\
\hline$\leq 4$ & 295 & 46.1 \\
\hline More than 4 & 345 & 53.9 \\
\hline \multicolumn{2}{|c|}{ Father's Educational Status* } \\
\hline Upto high school & 451 & 71.6 \\
\hline More than high school & 179 & 28.4 \\
\hline \multicolumn{2}{|c|}{ Mother's Educational Status** } \\
\hline Upto high school & 411 & 64.4 \\
\hline
\end{tabular}

\begin{tabular}{|c|c|c|}
\hline More than high school & 227 & 35.6 \\
\hline \multicolumn{3}{|c|}{ Father's Occupational Status* } \\
\hline Professional & 2 & 0.32 \\
\hline Semi-professional & 18 & 2.86 \\
\hline $\begin{array}{c}\text { Clerical, shop owner, } \\
\text { farmer }\end{array}$ & 219 & 34.76 \\
\hline Skilled worker & 161 & 25.56 \\
\hline Semi-skilled worker & 53 & 8.4 \\
\hline Unskilled worker & 177 & 28.1 \\
\hline \multicolumn{3}{|c|}{ Mother's Occupational Status** } \\
\hline Employed & 122 & 19.1 \\
\hline Unemployed & 516 & 80.9 \\
\hline \multicolumn{3}{|c|}{ SES } \\
\hline Upper & 2 & 0.3 \\
\hline Upper middle & 40 & 6.3 \\
\hline Lower middle & 373 & 58.3 \\
\hline Upper lower & 223 & 34.8 \\
\hline Lower & 2 & 0.3 \\
\hline
\end{tabular}

*10 fathers had passed away.

**2 mothers had passed away.

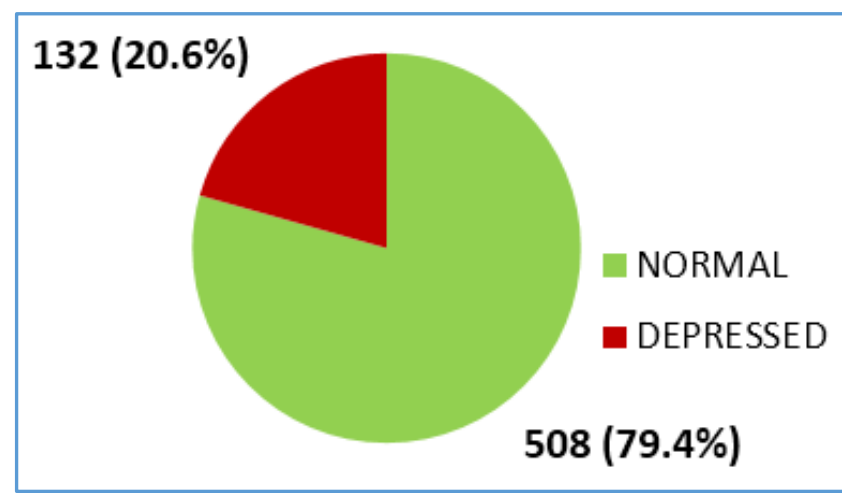

Figure 1. Prevalence of Depression $(n=640)$

Figure No. 1 shows that the prevalence of adolescent depression was $20.6 \%$ ( $\mathrm{CI}=20.6 \pm 2.56 \%$ ).

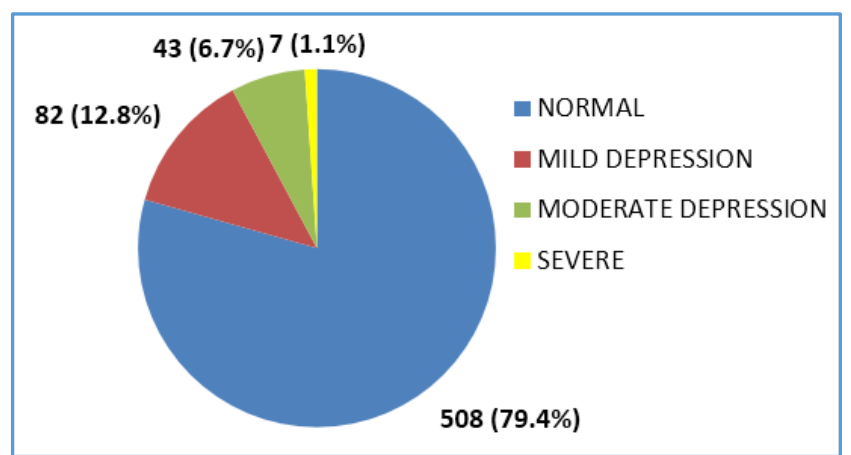

Figure 2. Level of Depression based on Hamilton Depression Rating Scale Score $(n=640)$

According to Figure No. 2, majority of the students had mild depression (12.8\%) followed by moderated depression $(6.7 \%)$ and severe depression $(1.1 \%)$. None of the students had very severe depression. 


\begin{tabular}{|c|c|c|c|c|c|}
\hline Characteristics & & Non-Depressed No. (\%) & Depressed No. (\%) & Total & P value \\
\hline \multirow{2}{*}{ Gender } & Male & $288(78.5)$ & $79(21.5)$ & $367(100)$ & \multirow{2}{*}{0.514} \\
\hline & Female & $220(80.6)$ & $53(19.4)$ & $273(100)$ & \\
\hline \multirow{2}{*}{ Class of study } & $\mathrm{X} 1$ & $270(82.8)$ & $56(17.2)$ & $326(100)$ & \multirow{2}{*}{0.028} \\
\hline & XII & $238(75.8)$ & $76(24.2)$ & $314(100)$ & \\
\hline \multirow{3}{*}{ Religion } & Hindu & $289(79)$ & $77(21)$ & $366(100)$ & \multirow{3}{*}{0.767} \\
\hline & Muslim & $206(79.5)$ & $53(20.5)$ & $259(100)$ & \\
\hline & Christian & $13(86.7)$ & $2(13.3)$ & $15(100)$ & \\
\hline \multirow{2}{*}{ Area of residence } & Rural & $263(82.2)$ & $57(17.8)$ & $320(100)$ & \multirow{2}{*}{0.079} \\
\hline & Urban & $245(76.6)$ & $75(23.4)$ & $320(100)$ & \\
\hline \multirow{2}{*}{ Type of school } & Government & $251(78.4)$ & $69(21.6)$ & $320(100)$ & \multirow{2}{*}{0.558} \\
\hline & Private & $257(80.3)$ & $63(19.7)$ & $320(100)$ & \\
\hline \multirow{2}{*}{ Type of family } & Nuclear & $288(77.6)$ & $83(22.4)$ & $371(100)$ & \multirow{2}{*}{0.20} \\
\hline & Joint & $220(81.8)$ & $49(18.2)$ & $269(100)$ & \\
\hline \multirow{2}{*}{ No. of family members } & $\leq 4$ & $232(78.6)$ & $63(21.4)$ & $295(100)$ & \multirow{2}{*}{0.67} \\
\hline & More than 4 & $276(80)$ & $69(20)$ & $345(100)$ & \\
\hline \multirow{2}{*}{ Father's educational status } & Upto high school & $348(77.2)$ & $103(22.8)$ & $451(100)$ & \multirow{2}{*}{0.013} \\
\hline & More than high school & $154(86)$ & $25(14)$ & $179(100)$ & \\
\hline \multirow{2}{*}{$\begin{array}{l}\text { Mother's educational } \\
\text { status }\end{array}$} & Upto high school & $326(79.3)$ & $85(20.7)$ & $411(100)$ & \multirow{2}{*}{0.994} \\
\hline & More than high school & $180(79.3)$ & $47(20.7)$ & $227(100)$ & \\
\hline \multirow{2}{*}{$\begin{array}{l}\text { Mother's occupational } \\
\text { status }\end{array}$} & Employed & $\begin{array}{c}94 \\
(77)\end{array}$ & $28(23)$ & $122(100)$ & \multirow[t]{2}{*}{0.493} \\
\hline & Unemployed & $412(79.8)$ & $104(20.2)$ & $516(100)$ & \\
\hline \multirow{2}{*}{ SES } & Upper + Middle* & $337(80.6)$ & $81(19.4)$ & $418(100)$ & \multirow{2}{*}{0.285} \\
\hline & Lower** & $171(77)$ & $51(23)$ & $222(100)$ & \\
\hline
\end{tabular}

*Upper includes upper, upper middle, lower middle. ** Lower includes upper lower, lower.

\begin{tabular}{|c|c|c|c|c|c|}
\hline Characteristics & & Non-Depressed No. (\%) & Depressed No. (\%) & Total & P-value \\
\hline \multirow{2}{*}{ Neglect } & Present & $20(44.4)$ & $25(55.6)$ & $45(100)$ & \multirow{2}{*}{$<0.001$} \\
\hline & Absent & $488(82)$ & $107(18)$ & $595(100)$ & \\
\hline \multirow{2}{*}{ Physical abuse } & Present & $7(36.8)$ & $12(63.2)$ & $19(100)$ & \multirow{2}{*}{$<0.001^{*}$} \\
\hline & Absent & $501(80.7)$ & $120(19.3)$ & $621(100)$ & \\
\hline \multirow{2}{*}{ Death of parents/ relatives } & Present & $193(74.8)$ & $65(25.2)$ & $258(100)$ & \multirow{2}{*}{0.019} \\
\hline & Absent & $315(82.5)$ & $67(17.5)$ & $382(100)$ & \\
\hline \multirow{2}{*}{ High level of conflict in the family } & Present & $14(45.2)$ & $17(54.8)$ & $31(100)$ & \multirow{2}{*}{$<0.001$} \\
\hline & Absent & $494(81.1)$ & $115(18.9)$ & $609(100)$ & \\
\hline \multirow{2}{*}{ Parental divorce } & Present & $1(33.3)$ & $2(66.7)$ & $3(100)$ & \multirow{2}{*}{$0.11^{*}$} \\
\hline & Absent & $507(79.6)$ & $130(20.4)$ & $637(100)$ & \\
\hline \multirow{2}{*}{$\begin{array}{c}\text { Poor communication at home and } \\
\text { school }\end{array}$} & Present & $23(46)$ & $27(54)$ & $50(100)$ & \multirow{2}{*}{$<0.001$} \\
\hline & Absent & $485(82.2)$ & $105(17.8)$ & $590(100)$ & \\
\hline \multirow{2}{*}{ Parental rejection } & Present & $58(58.6)$ & $41(41.4)$ & $99(100)$ & \multirow{2}{*}{$<0.001$} \\
\hline & Absent & $450(83.2)$ & $91(16.8)$ & $541(100)$ & \\
\hline \multirow{2}{*}{ Peer rejection } & Present & $57(67.1)$ & $28(32.9)$ & $85(100)$ & \multirow{2}{*}{0.003} \\
\hline & Absent & $451(81.3)$ & $104(18.7)$ & $555(100)$ & \\
\hline \multirow{2}{*}{ Staying in hostel } & Present & $4(80)$ & $1(20)$ & $5(100)$ & \multirow{2}{*}{$1.0^{*}$} \\
\hline & Absent & $504(79.4)$ & $131(20.6)$ & $635(100)$ & \\
\hline \multirow{2}{*}{ Parents working abroad } & Present & $126(75.4)$ & $41(24.6)$ & $167(100)$ & \multirow{2}{*}{0.15} \\
\hline & Absent & $382(80.8)$ & $91(19.2)$ & $473(100)$ & \\
\hline \multirow{2}{*}{ Family history of depression } & Present & $5(45.5)$ & $6(54.5)$ & $11(100)$ & \multirow{2}{*}{$0.01^{*}$} \\
\hline & Absent & $503(80)$ & $126(20)$ & $629(100)$ & \\
\hline
\end{tabular}

*Fisher's exact test.

\begin{tabular}{|c|c|c|c|c|c|}
\hline Characteristics & & Non-Depressed No. (\%) & Depressed No. (\%) & Total & P-value \\
\hline Failure in exams & Present & $200(71.4)$ & $80(28.6)$ & $280(100)$ & $<0.001$ \\
\cline { 2 - 6 } & Absent & $308(85.6)$ & $114(19.5)$ & $560(100)$ & $0.02(100)$ \\
\hline \multirow{2}{*}{$\begin{array}{c}\text { Having someone to discuss } \\
\text { worries with }\end{array}$} & Present & $471(80.5)$ & $18(32.7)$ & $55(100)$ & 0.02 \\
\cline { 2 - 6 } & Absent & $37(67.3)$ & $10(47.6)$ & $21(100)$ & $0.004^{*}$ \\
\hline $\begin{array}{c}\text { Career disagreement between } \\
\text { the student and parent }\end{array}$ & Present & $11(52.4)$ & $122(19.7)$ & $619(100)$ & $18(100)$ \\
\cline { 2 - 6 } $\begin{array}{c}\text { University disagreement } \\
\text { between the student and the } \\
\text { parent }\end{array}$ & Absent & $497(80.3)$ & $10(55.6)$ & $6.001^{*}$ \\
\cline { 2 - 6 } & Present & $8(44.4)$ & $122(19.6)$ & $622(100)$ & \\
\hline
\end{tabular}




\section{DISCUSSION}

The prevalence of depression was found to be $20.6 \%$ in our study. This was comparable to the study conducted at Imphal, Manipur where the prevalence rate was $19.5 \% .^{15}$ Indian studies have shown prevalence ranging from $18.4 \%$ to 38\%.16-18 A study conducted by Russell $\mathrm{P}$ et al found the prevalence of depression to be $13.9 \% .^{7}$

In this study, males $(21.5 \%)$ were more depressed than females (19.4\%). Similar findings were seen in the study conducted by Nagendra K et al. ${ }^{19}$ A study by Chauhan S et al found females to be significantly more depressed than males. ${ }^{18}$ The prevalence of depression among students studying in class XII (24.2\%) was significantly more than students studying in class XI (17.2\%). This may be because they are in pressure regarding their performance in board examination. This finding was consistent with the study conducted in South India. ${ }^{17}$

The prevalence of depression was more among students residing in urban area compared to students residing in rural area. Students studying in government schools were more depressed than students studying in private schools. These findings were consistent with the study conducted by Vashisht A et al.20

Students belonging to joint family (18.2\%) were less depressed than students belonging to nuclear family (22.4\%). It may be because in joint family system, all the members may work together to solve a problem faced by any one member of the family. Similar findings were seen in a study conducted by Nagendra Ket al. ${ }^{19}$

Father's educational status was significantly associated with depression. Few studies have reported similar association with father's educational status. ${ }^{21,22}$ Depression was more among students whose mothers were employed. Students belonging to lower SES were more depressed compared to students from higher SES. An observation similar to a study was conducted in Turkey. ${ }^{23}$

Neglect and abuse had an effect on the prevalence of adolescent depression, an observation similar to a study conducted by Brown J et al. ${ }^{24}$

The prevalence of depression was more among those students who had parental divorce, death of parents/ relatives. Similar findings were seen in the study conducted in Turkey. ${ }^{23}$

Depression was found to be more among students whose parents were working abroad (24.6\%) compared to students whose parents were not working abroad (19.2\%). Staying away from parents was found to be a significant risk factor for depression in children. In Kerala due to socio-economic reasons, there are several children who stay in hostels or orphanages or have parents working abroad. These children form a vulnerable group who need more attention. ${ }^{25}$

Factors like high level of conflict, poor communication at home and school, parental rejection and peer rejection were significantly associated with depression. Few studies showed similar findings. ${ }^{16,26-28}$

The prevalence of depression among adolescents who had a family history of depression $(54.5 \%)$ was more than those who did not have a family history of depression (20\%). Similar findings were seen in a study conducted by Muhil M. ${ }^{29}$

The examination related stressors like having anyone to talk to about his/ her worries, poor academic achievement and parents not agreeing with student's choice of university and career were associated with depression. These findings are consistent with the study conducted in Japan. ${ }^{30}$ The study conducted by Krishnakumar P and Geeta MG found a significant association between examination failures and depression. ${ }^{25}$

\section{CONCLUSION}

This study highlights the prevalence of depression among higher secondary school students. This finding emphasises the need for screening depression and identifying adolescents who need further intervention. Teachers and parents should be able to identify depression at earlier stage, so that the risk of progression into other serious problems like drug abuse, suicide and violence can be minimised. Health education to parents as well as to community as a whole should be promoted to remove the stigma attached to these disorders. Emphasis should also be on IEC activities to ensure recognition of even mild symptoms of depression and their early treatment. It seems necessary to have a post of counsellor in every school for early identification of adolescents suffering from depression.

\section{REFERENCES}

[1] WHO. Adolescent heath, 2012 [cited 2015 Nov 17]. http://www.who.int/topics/adolescent_health/en/

[2] Suryakantha AH. Community Medicine with recent advances. New Delhi: Jaypee Brothers Medical Publishers 2014.

[3] WHO. WHO calls for stronger focus on adolescent heath, 2014 [updated 2014 May 14; cited 2015 Oct 17].

http://www.who.int/mediacentre/news/releases/20 14/focus-adolescent-health/en/

[4] World Health Organization. Caring for children and adolescents with mental disorders. Geneva: World Health Organization 2003.

[5] Lewinsohn P. Depression in adolescents. In: Gotlib IH, Hammen CL, eds. Handbook of depression. $1^{\text {st }}$ edn. New York: Guilford Press 2002.

[6] Naik U. Magnitude of mental health problems in adolescence. In: Mehta M, Sagar R, eds. A practical approach to cognitive behaviour therapy in adolescents. $1^{\text {st }}$ edn. New Delhi: Springer Publishing 2015.

[7] Russell PS, Nair MK, Shankar SR, et al. Relationship between depression and anxiety disorders among adolescents in a rural community population in India. Indian J Pediatr 2013;80(Suppl 2):165-70.

[8] NIMHANS. National Mental Health Survey of India, 2015-16. Prevalence, pattern and outcomes. 2016 [cited 2016 Jul 3]. http://www.nimhans.ac.in

[9] Mexas. Levels or stages of education in India today $2010 \quad$ [cited 2015 Oct 24]. https://revivingindianeducation.wordpress.com/abou $\mathrm{t} /$ levels or stages of education in India today.

[10] Mohamedayupkhan M, Mani S. A study on higher secondary students personal problems, study involvement and academic achievement. IJSR 2014;3(5):876-82.

[11] WHO. The ICD-10 classification of mental and behavioural disorders. Geneva: AITBS Publishers 2007. 
[12] Elizabeth H, Pamela S, David D. Risk and vulnerability in adolescent depression. In: Cecilia $\mathrm{AE}$, eds. Treatment of adolescent depression. $7^{\text {th }}$ edn. London: Oxford University Publishing 2015.

[13] Hankin BL, Young JF, Abela JR, et al. Depression from childhood into late adolescence: influence of gender, development, genetic susceptibility and peer stress. J Abnorm Psychol 2015;124(4):803-16.

[14] Weissman MM, Wolk S, Goldstein RB, et al. Depressed adolescents grown up. JAMA 1999;281(18):1707-13.

[15] Kumar KS, Akoijam BS. Depression, anxiety and stress among higher secondary school students of Imphal, Manipur. Indian J Community Med 2017;42(2):94-6.

[16] Bansal V, Goyal S, Srivastava K. Study of prevalence of depression in adolescent students of a public school. Ind Psychiatry J 2009;18(1):43-6.

[17] Jayanthi P, Thirunavakarasu M. Prevalence of depression among school going adolescents in south India. IJPCR 2015;7(1):61-3.

[18] Chauhan S, Lal P, Nayak H. Prevalence of Depression among School Children aged 15 years and above in a Public School in Noida, Uttar Pradesh. JAIR 2014;3(6):269-73.

[19] Nagendra K, Sanjay D, Gouli C, et al. Prevalence and association of depression and suicidal tendency among adolescent students. IJBAR 2012;3(9):714-9.

[20] Vashisht A, Gadi NA, Singh J, et al. Prevalence of depression and assessment of risk factors among school going adolescents. Ind J Comm Health 2014;26(2):196-9.

[21] Daryanavard A, Madani A, Mahmoodi MS, et al. Prevalence of depression among high school students and its relation to family structure. Am J Applied Sci 2011;8(1):39-44.
[22] Eskin M, Ertekin K, Harlak H, et al. Prevalence of and factors related to depression in high school students. Turk Psikiyatri Derg 2008;19(4):382-9.

[23] Bodur S, Kücükkendirci H. Prevalence of depressive symptoms in Turkish adolescents. Eur J Gen Med 2009;6(4):204-12.

[24] Brown J, Cohen P, Johnson JG, et al. Childhood abuse and neglect: specificity of effects on adolescent and young adult depression and suicidality. J Am Acad Child Adolesc Psychiatry 1999;38(12):1490-6.

[25] Krishnakumar P, Geeta MG. Clinical profile of depressive disorder in children. Indian Pediatr 2006;43(6):521-6.

[26] Vazsonyi AT, Belliston LM. The cultural and developmental significance of parenting processes in adolescent anxiety and depression symptoms. Journal of Youth and Adolescence 2006;35(4):491-505.

[27] Naz F, Kausar R. Parental rejection, personality maladjustment and depressive symptoms in female adolescents in Pakistan. J Humanities and Social Science 2013;14(1):56-65.

[28] Braet C, Van Vlierberghe L, Vandevivere E, et al. Depression in early, middle and late adolescence: differential evidence for the cognitive diathesis-stress model. Clin Psychol Psychother 2013;20(5):369-83.

[29] Muhil M, Umapathysembian. Status of depression among school children \& adolescents in urban areas of Tamilnadu. IOSR-J Dental and Medical Sciences 2015;14(7):117-9.

[30] Koyama A, Matsushita M, Ushijima H, et al. Association between depression, examination-related stressors and sense of coherence: The Ronin-Sei study. Psychiatry Clin Neurosci 2014;68(6):441-7. 